\title{
Minimal to No Esophageal Clearance Following Swallowing
}

National Cancer Institute

\section{Source}

National Cancer Institute. Minimal to No Esophageal Clearance Following Swallowing.

NCI Thesaurus. Code C127348.

A finding of minimal to no esophageal clearance. 